\title{
ARTIGO
}

do https://doi.org/10.22481/praxisedu.v15i36.5940

\section{TEACHING AND UPBRINGING OF STUDENTS IN HIGHER EDUCATIONAL INSTITUTIONS, TAKING INTO ACCOUNT THE REQUIREMENTS OF A LEARNER-CENTRED APPROACH}

\author{
ENSEÑANZA Y EDUCACIÓN DE ESTUDIANTES EN INSTITUCIONES DE \\ EDUCACIÓN SUPERIOR, TENIENDO EN CUENTA LOS REQUISITOS DE UN \\ ENFOQUE CENTRADO EN EL ALUMNO
}

\author{
ENSINO E EDUCAÇÃO DE ESTUDANTES EM INSTITUIÇÕES DE ENSINO \\ SUPERIOR, LEVANDO EM CONSIDERAÇÃO OS REQUISITOS DE UMA \\ ABORDAGEM CENTRADA NO ALUNO
}

Nosov Magnitogorsk State Technical University, Magnitogorsk - Russia

Olga V. Mikhina

Nosov Magnitogorsk State Technical University, Magnitogorsk - Russia

Tatyana Yu. Baklykova Nosov Magnitogorsk State Technical University, Magnitogorsk - Russia

Roman R. Vakhitov

Nosov Magnitogorsk State Technical University, Magnitogorsk - Russia

Svetlana S. Velikanova

Nosov Magnitogorsk State Technical University, Magnitogorsk - Russia

Oksana P. Chernykh

Nosov Magnitogorsk State Technical University, Magnitogorsk - Russia

Abstract: The presented paper is devoted to the issue of organization of upbringing teaching for students which are learners in higher educational institutions. Based on the works of I.A. Zimnyaya, T.I. Ilyin, V.V. Kraevsky, G.M. Kodzhaspirova, I. Ya. Lerner, I.F. Kharlamov and other researchers, the authors clarified the concept of "upbringing teaching for university 
students", analysed its components, systematised domestic and foreign experience in organizing upbringing teaching for students in higher educational institutions. The paper also presents the author's complex of pedagogical conditions that promotes the organization of upbringing teaching for university students. The complex includes the following components: correction of students' value orientations in the educational process of a university; the development of cognitive activity of students and the construction of the educational process at a university taking into account the requirements of a learner-centred approach.

Keywords: Upbringing teaching; University students; Learner-centred approach to education; Cognitive activity of students; Value orientations of university students.

Resumen: El documento presentado está dedicado al tema de la organización de la enseñanza de la educación para los estudiantes que aprenden en instituciones de educación superior. Basado en los trabajos de I.A. Zimnyaya, T.I. Ilyin, V.V. Kraevsky, G.M. Kodzhaspirova, yo. Ya. Lerner, I.F. Kharlamov y otros investigadores, los autores aclararon el concepto de "enseñanza de educación para estudiantes universitarios", analizaron sus componentes, sistematizaron la experiencia nacional y extranjera en la organización de la enseñanza de educación para estudiantes en instituciones de educación superior. El documento también presenta el complejo de condiciones pedagógicas del autor que promueve la organización de la enseñanza de educación para estudiantes universitarios. El complejo incluye los siguientes componentes: corrección de las orientaciones de valor de los estudiantes en el proceso educativo de una universidad; El desarrollo de la actividad cognitiva de los estudiantes y la construcción del proceso educativo en una universidad teniendo en cuenta los requisitos de un enfoque centrado en el alumno.

Palabras clave: Enseñanza y educación; Estudiantes universitarios; Enfoque de la educación centrado en el alumno; Actividad cognitiva de los estudiantes; Orientaciones de valor de los estudiantes universitarios.

Resumo: O artigo apresentado é dedicado à questão da organização do ensino de educação para alunos aprendentes em instituições de ensino superior. Baseado nos trabalhos de I.A. Zimnyaya, T.I. Ilyin, V.V. Kraevsky, G.M. Kodzhaspirova, I. Ya. Lerner, I.F. Kharlamov e outros pesquisadores, os autores esclareceram o conceito de "ensino de educação para estudantes universitários", analisaram seus componentes, sistematizaram a experiência nacional e estrangeira na organização do ensino de educação para estudantes em instituições de ensino superior. O artigo também apresenta o complexo de condições pedagógicas do autor que promove a organização do ensino de educação para estudantes universitários. O complexo inclui os seguintes componentes: correção das orientações de valor dos alunos no processo educacional de uma universidade; o desenvolvimento da atividade cognitiva dos estudantes e a construção do processo educacional em uma universidade, levando em consideração os requisitos de uma abordagem centrada no aluno.

Palavras-chave: Ensino e educação; Estudantes universitários; Abordagem educacional centrada no aluno; Atividade cognitiva dos alunos; Orientações de valor para estudantes universitários. 


\section{Introduction}

The organization of upbringing teaching is one of the most pressing problems of modern pedagogical science and practice. Learning activities of students are the source of the diversification of their personalities, affecting not only the system of value orientations, but also their attitude to society, to work, to people and to themselves. In modern conditions of transition to multi-level and variative education, in connection with the profiling of educational programs and more targeted individualization of their choice, upbringing opportunities of teaching increase (Bernard, 1965; Shure, 1981; Akulova et al, 2016). Therefore, the upbringing teaching of university students is an important stage in continuing education. In its conditions, a focus is formed on continuing education and self-education, the need for continuous cognitive activity, without which professional education and the achievement of professional mastery are impossible (Alekseeva, 2007; Neretina \& Klevesenkova, 2017; Bogomolova, 2009).

\subsection{Relevance of the problem}

The relevance of the problem on organizing upbringing teaching for students in higher education institutions is determined by a number of contradictions:

1. Pedagogic problems are often perceived by university teachers as an additional burden that distracts them from teaching specific subjects.

2. There is an erroneous opinion that teaching and upbringing processes are implemented in parallel, while in an integral pedagogical process they appear together and simultaneously.

3. There is a misunderstanding of an upbringing process as a complex of special events that should be carried out by someone other than a teacher and separately from the educational process in a university (Bodalev, 1995; Goncharov, 2004; Zimnaya, 2003).

It must be remembered that a gradual introduction of students into the universal and national culture and science, to the formation of their own personality as a subject of life take place through teaching and learning. Awareness of the social value of education has a beneficial effect on the activity of individuals and their motivation. 


\section{Problem study}

Historical and pedagogical analysis of various sources allows us to suggest that the problem of the relationship between upbringing and teaching has long worried pedagogical thought. So, even Plato in his "Laws" argued that the most important thing in teaching is proper upbringing (Khayrullov, 2005; Ardashkin et al, 2015; Arokiasamy et al, 2013). In the following centuries, many attempts were made to define upbringing and teaching, to separate these processes and analyse their relationship. The concept of "upbringing teaching" was introduced into pedagogy by I.F. Herbart (1776-1841), who considered teaching as the main means of upbringing. At the same time, he distinguished upbringing and teaching as processes specific by their goals, means and results, but united by a common focus on bringing a pupil closer to virtue, i.e. the ideal of a man of education (Polyakova \& Lushkina, 2011; Sarantsev, 2016; Serikov, 1994).

In Russian pedagogy at the second half of the XIX - early XX centuries, upbringing teaching was considered as the main means of educating a spiritual and moral personality (K.D. Ushinsky, V.P. Vakhterov, P.F. Kapterev, etc.).

The provision on the indissolubility of upbringing and ccc0th century (Yu.K. Babansky, T.I. Ilyina, I.F. Kharlamov, etc.). So, I. Ya. Lerner, V.V. Kraevsky, V.A. Petrovsky, B.M. Bim-Bad and others defined upbringing and teaching as the subsystems of a single process - education.

In our study, we rely on the ideas of I.Ya. Lerner, who defined education and upbringing as a single process, involving the assimilation by students of knowledge, skills, experience of creative activity and emotional upbringing. Moreover, if the first three elements determine the level of intellectual development of a person, then the complex of these components makes up the content of the spiritual development of the personality as a whole.

\section{Hypothesis}

University students will be taught upon the implementation of the complex of the following pedagogical conditions:

1) Correction of students' value orientations in the educational process of the university.

2) The development of cognitive activity of students. 
3) The build-up of the educational process in the university taking into account the requirements of a learner-centred approach.

\section{Methods}

The authors developed the idea of upbringing teaching for university students based on the principles of consistency, activity, humanization, individualization, feedback, integration at the level of interdisciplinary connections, reflective activity and problematicity. The work is based on the following methods: theoretical - analysis, generalization, systematization, synthesis, modelling; and empirical - conversation, observation, quantitative and qualitative analysis of research results, testing.

\section{Main part}

Based on the works of G.M. Kodzhaspirova, I.A. Zimnyaya, I.F. Kharlamov and other researchers, we consider upbringing teaching as a teaching, in which an organic link is achieved between acquiring by students the knowledge, skills, mastering the experience of creative activity and the formation of an emotionally valuable attitude to the world, to each other, to the material under studied. The authors of the paper are convinced that a holistic approach to upbringing in the teaching process involves the unity of all components of the didactic process: goals and objectives, content, methods and forms of organization of teaching and its results, and pedagogical guidance. The integration of the functions inherent in the individual components of upbringing teaching is not a sum, but a new qualitative phenomenon, the essence of which is expressed in the mutual influence and dynamics of education in a single process.

1. The goals and objectives of upbringing teaching. The holistic construction of upbringing teaching is based on the integration of goals that are addressed to the personality of a student and a teacher. The dynamics of the unity of upbringing and teaching, and its procedural orientation are adjusted during the implementation of educational programs, taking into account the quality of innovative activity, and also taking into account subjective factors, in particular, the axiological attitude of teachers and students to cooperation and joint activities. Teachers update educational goals on the basis of their relevance, promise, continuity and approach to the ultimate goals. The effectiveness of the entire educational process depends 
on the timely, clear, well-thought-out setting of upbringing goals in unity with the goals of teaching.

2. The content of upbringing teaching. The main purpose of the upbringing teaching content consists, first of all, in providing a cognitive basis for the development of students' personalities, mastering the system of integrated knowledge and skills, and in encouraging students to continuous self-education. University students feel their involvement in social culture, progress, civilization, the development of science and technology through the content of teaching, and mastering the system of scientific knowledge. The future of social development is closely connected with what the younger generation is taught in higher education. The content of teaching also forms the basis for the formation of a scientific worldview and students' beliefs. University education is becoming a factor of social significance. Being relevant, the problem of integrating scientific knowledge, a combination of theoretical and specific knowledge, the study of scientific concepts, theories, fundamental laws of the development of nature and society, and methods of science elevates personality as an inherent worth in the "man-man" system, making it capable of transforming reality. The ability to analyse and evaluate new facts, to operate with previously acquired knowledge in new situations, to make deeper and more generalized conclusions provides a free choice of one's position in difficult life situations.

3. Methods of upbringing teaching. The cognitive activity of students, in which cognitive and upbringing actions are performed simultaneously, depends on the choice of teaching methods and the upbringing methods associated with them. The upbringing function of teaching methods is realized through updating the students' professional knowledge, through the development of an active, creative, cognitively transforming position of students, and through the application of their skills. For example, the method of cognitive conversation develops into a method of discussion on ethical topics; a problem situation causes not only cognitive, but also moral activity; the oncoming movement of questions from a teacher and students arouses mutual interest in cognition, and reinforces research abilities and skills. The merging of teaching and upbringing methods into a single pedagogical process allows us to more deeply study the methodological problems of science with students, and to link teaching with actual problems of life. 
4. Organizational forms of the upbringing teaching. The upbringing functions of the educational activity organizational forms are fully manifested if the teacher manages to recreate norms of behaviour in the experience of students' practical relationships, to combine the organization of learning with the formation of experience in humanistic relationships between students and between students and teachers. For our study, it is important that a well-thought-out teaching organization generates friendly relations between students. An elevated, major tone combined with efficiency and seriousness, make educational work meaningful and enjoyable for students to the extent possible not only in terms of knowledge acquisition, but also in terms of meeting communication needs.

5. The pedagogical management of the upbringing teaching process. The effectiveness of pedagogical guidance of the upbringing teaching process depends on the teacher's professional and pedagogical preparedness for the implementation of educational and upbringing tasks, as well as on the style of his her relationship with students. The relations between a teacher and students, which make up the personal basis of pedagogical interaction, have external and internal sides. The external side is manifested in the ways of presenting requirements, in an individual approach to students, etc., and internal in mutual understanding and empathy in the normal course of business, the adequacy of actions, assessments, and judgments. The driving force of development is the orientation of a teacher on the personal achievements of students and their life values.

6. The results of upbringing teaching. As for the learning outcomes, it should be noted that upbringing teaching is closely related to the comprehensive development of persons. Students assimilate multi-subject knowledge, master generalized cognitive skills, form a creative attitude towards their future professional activities. At the same time, comprehension of scientific knowledge is enriched by moral content. Education takes on a deep humanistic meaning. It develops, becomes more complex, and the whole personality of a student forms along with it and ripens in all the richness and variety of manifestations.

Thus, upbringing teaching involves not only the assimilation by university students of knowledge about nature and society, the norms of behaviour, but also requires a personal attitude to the assimilated worldview and moral concepts, the development on their basis of a 
system of views and beliefs that become principles and motives of behaviour. This goal can be achieved through the interaction between all components of upbringing teaching: goals and objectives, content, methods and forms of organization of teaching and its results, and pedagogical guidance.

In our opinion, upbringing teaching at universities will be effective if the following pedagogical conditions are met:

4) Correction of students' value orientations in the educational process of a university.

5) The development of cognitive activity of students.

6) The construction of the educational process in a university taking into account the requirements of the learner-centred approach.

Let's consider them in more detail:

1) University education provides a student with a set of the most important values which helshe brings under deliberation, gives them evaluative insights, and which then have been mastered by himlher.

From a pedagogical point of view, that matters which are useful for the student's life, which contribute to the development and improvement of his thwe personality should be considered values. Value can be both a phenomenon of the external world (object, thing, event, act), and a fact of thought (idea, image, scientific concept). It is necessary to clearly imagine that each discipline is, in essence, only a part of the values from the whole complex of scientific, artistic, ethical, aesthetic and other values that have already been created for humanity and proceed from this work with the student, not allowing to hypertrophy the significance of ones and underestimate others academic subjects. All of them are basically interconnected by a humanistic principle and are aimed at the formation of the student's comprehensive life experience, high culture, mutual understanding with other people.

2) Cognitive activity as a pedagogical phenomenon is a two-way interconnected process in which cognitive activity, on the one hand, is a form of self-organization and self-realization of students; on the other hand, it is considered as a result of teacher's special efforts in organizing the cognitive activity of students. Different students are characterized by different intensities in active learning. The authors of the paper developed a typology of cognitive activity of university students, which 
includes such levels as: relatively active level; performing-active level, and creative level. The tactics of educational interaction between a teacher and students of each level were also developed, refined and experimentally tested; methodological recommendations for university teachers were published.

3) However, it should be noted that the implementation of the above conditions is possible only with reliance on the personality of the learners, on their worldview and subjective experience. Therefore, for the successful organization of upbringing teaching at a university, it is necessary to rely on the principles of a learner-centred approach, since it provides for the creation of conditions for the development of students in accordance with their natural data and personal interests. The basis of the learner-centred approach is the recognition of the individuality, originality of each person, his/her development not as a "collective subject", but primarily as an individual endowed with his/her own unique subjective experience. We emphasize that the implementation of learner-centred learning requires the development of such a content of education, which includes not only scientific knowledge, but also meta-knowledge, i.e. receptions and methods of scientific knowledge.

The experimental work aimed at checking the selected set of pedagogical conditions was carried out in vivo in the educational process of the university in 2017 - 2019. The participants in the pedagogical experiment were 1-4 year students of technical and pedagogical specialties. In total, about 200 people took part in the experiment, including 16 teachers.

\section{Conclusions}

Summing up the study, the following can be noted.

The novelty and theoretical significance of the study consists in clarifying the content of the concept "upbringing teaching for university students" and analysing its components.

The practical significance of the presented study lies in the fact that it systematizes domestic and foreign experience in organizing upbringing teaching for students in a higher educational institution. Based on it, a set of measures has been developed that allows the value orientations and levels of cognitive activity of students to form and, if necessary, to adjust based on the personal orientation of their educational activities.

All of the above allows us to draw the following conclusion: the teaching of university students will be upbringing in the case of correction of students' value orientations in the 
university educational process; the development of cognitive activity of students and the construction of the educational process in a university taking into account the requirements of a learner-centred approach; this confirms the hypothesis put forward by the authors.

\section{Conflict of interest}

The authors confirm that the data presented do not contain a conflict of interest.

\section{REFERENCES}

1. Akulova I.S., Velikanova S.S., Plotnikova E.B., Khakova G.S., Chernykh O.P., Chernobrovkin V.A. (2016). Experiences of tolerance: historical and philosophical analysis of multiculturalism (by the example of Magnitogorsk, Russia), The Social Sciences (Pakistan), 11(3), 6532-6535. [in English].

2. Alekseeva L.F. (2007). Psychological competence of a teacher in higher education, Higher education in Russia, No. 8. [In Russian].

3. Ardashkin I., Martyushev N., \& Bezborodov V. (2015). Problem Methodology as One of the Ways of Innovative Organization of Educational Process. Procedia - Social and Behavioural Sciences, 166, 227-231. [in English].

4. Arokiasamy A., Hon Tat.H., \& Abdullah A. (2013). The effects of rewards system and motivation on job satisfaction: Evidence from the education industry in Malaysia. World Applied Sciences Journal, 24 (12), 1597-1604. [in English].

5. Bernard H.W. (1965). Psychology of Learnind \& Teaching.NY. [in English].

6. Bodalev A. A. (1995). Fundamentals of socio-psychological theory. M., 1995. [in Russian].

7. Bogomolova E.V. (2009). Methodology and didactics for preparing a teacher for the implementation of learner-centred teaching, Moscow State University Bulletin, 146150. [in Russian].

8. Goncharov S.Z. (2004). Social competence of an individual: essence, structure, criteria and significance, Education and Science, 2(26), 3 - 18. [in Russian].

9. Khayrullov Zh. R. (2005). Formation of personality self-actualization in a professional orientation, Integration of Education, 3, 156-160. [in Russian].

10. Neretina T.G., Klevesenkova S.V. (2017). Education of student family values through the exhibition "Human Potential of Russia", Magnitogorsk: Publishing house of Magnitogorsk State Technical University named after G.I. Nosov, 1(1), 50-54. [in Russian].

11. Polyakova O.O., Lushkina M.P. (2011). Features of the professional identity of modern students, Herald of Moscow State University, 2, 69-73. [in Russian].

12. Sarantsev G.I. (2016). Harmonization of professional teaching of a bachelor in the direction of "Pedagogical education", Integration of education, 2, 211-219. [in Russian].

13. Serikov V.V. (1994). Personal approach in education: concepts and technologies: monograph. Volgograd: Change, 150 p. [in Russian]. 
14. Shure M.B. (1981). Social Competence as a Problem-solving Skill / M.B. Shure, Social competence, edited by Jeri Dawn Wine \& Marti Diane Smye. - New York, London: The Guilford Press, 158-185. [in English].

15. Zimnaya I. A. (2003). Key competencies: a new paradigm of the education result, Higher education today, No. 5. [in Russian].

\section{SOBRE OS AUTORES:}

\section{Olga L. Nazarova}

Prof. D. of Pedagogical Sciences, Nosov Magnitogorsk State Technical University, 38 Lenin Avenue, 455000, Chelyabinsk Region, Magnitogorsk, Russia. E-mail: info@ores.su

(iD) http://orcid.org/0000-0002-0885-329X

\section{Olga V. Mikhina}

Ph.D., Nosov Magnitogorsk State Technical University, 38 Lenin Avenue, 455000, Chelyabinsk Region, Magnitogorsk, Russia. E-mail: belova-t@ores.su

(iD http://orcid.org/0000-0002-9388-898X

\section{Tatyana Yu. Baklykova}

Ph.D., Nosov Magnitogorsk State Technical University, 38 Lenin Avenue, 455000, Chelyabinsk Region, Magnitogorsk, Russia. E-mail: ssv@ores.su

iD http://orcid.org/0000-0002-2936-0427

\section{Roman R. Vakhitov}

Ph.D., Nosov Magnitogorsk State Technical University, 38 Lenin Avenue, 455000, Chelyabinsk Region, Magnitogorsk, Russia. E-mail: editor@ores.su

(iD) http://orcid.org/0000-0002-7347-1087

\section{Svetlana S. Velikanova}

Ph.D., Nosov Magnitogorsk State Technical University, 38 Lenin Avenue, 455000, Chelyabinsk Region, Magnitogorsk, Russia. E-mail: russia@ prescopus.com

iD http://orcid.org/0000-0001-8741-2195

\section{Oksana P. Chernykh}

Ph.D., Moscow University of Finance and Law MFUA, 17/1 Serpukhov Val str., 115191,

Moscow, Russia. E-mail: p.chernykh2019@gmail.com

iD http://orcid.org/0000-0002-0296-9101 